\title{
Effects of using essential oil of Lavandula stoechas in quail feed on growth performance, carcass characteristics, meat quality, and health status
}

\author{
Ouafa Laghouati ${ }^{1}$, Fodil Arbouche ${ }^{2}$ iD and Yasmine Arbouche ${ }^{3}$
}

\author{
1. Department of Veterinary, Faculty of Life and Earth Sciences, University of Chadli bendjedid, El Tarf, 36000 Algeria \\ 2. Department of Agronomy, Faculty of Life and Earth Sciences, University of Ghardaia, Ghardaia, 47000 Algeria; \\ 3. Department of Agronomy, Faculty of Life Sciences, University of Sétif 1, El Bez, Sétif 19000, Algeria. \\ Corresponding author: Fodil Arbouche, e-mail: arbouchefodil@yahoo.fr \\ Co-authors: OL: laghouatiwafaa125@gmail.com, YA: yas.arbouche@yahoo.fr \\ Received: 13-12-2019, Accepted: 11-03-2020, Published online: 26-04-2020
}

doi: www.doi.org/10.14202/vetworld.2020.789-795 How to cite this article: Laghouati O, Arbouche F, Arbouche Y (2020) Effects of using essential oil of Lavandula stoechas in quail feed on growth performance, carcass characteristics, meat quality, and health status, Veterinary World, 13(4): 789-795.

\begin{abstract}
Aim: The aim of this study was to determine the effects of essential oil of Lavandula stoechas (Lavender) on growth performance, carcass characteristics, meat quality, and health status of quails.

Materials and Methods: A group of 600 1-day-old Japanese quail chicks (Coturnix japonica), with an average weight of $6.8 \pm 0.2 \mathrm{~g}$ and a 1:1 sex ratio, were randomly assigned to four groups (150 chicks/group): three experimental groups which depend on the incorporation of lavender oil (LO) in the different phases of breeding and one control group. The experimental groups received a supplement of $1 \mathrm{~g} \mathrm{LO}$ per $\mathrm{kg}$ of feed distributed sequentially throughout the entire 42-day breeding period.

Results: No deaths were recorded throughout the breeding period. Highly significant differences were observed among the groups with regard to body weight measured on day 20 and day $42(\mathrm{p}<0.001$ and $\mathrm{p}<0.01$, respectively). The addition of LO was accompanied by reductions in liver weights; furthermore, $\mathrm{LO}$ had a significant effect on the $\mathrm{pH}$, water content, and fat content of the meat $(\mathrm{p}<0.05)$. Administration of LO had a measurable effect on the endogenous intestinal population of Lactobacillus, and the bacterial load (including those of Escherichia coli and Staphylococcus aureus) was significantly reduced.
\end{abstract}

Conclusions: Our results demonstrate that supplementing quail feed with LO has a profound effect on their growth as well as antimicrobial effects.

Keywords: fat content, Japanese quail, lavender oil, microbial load, water content, zootechnical performance.

\section{Introduction}

Antibiotics have long been used to stimulate growth of commercial poultry and to improve the production of white meat [1]. Antibiotic resistance and the harmful effect of their widespread use on both human and animal health have forced nutritionists and livestock production managers to find suitable alternatives [2]. Several recent studies have suggested that plant extracts, including essential oils, are effective replacements for antibiotics and boost zootechnical performance [3-8].

Among the aromatic plants indigenous to Algeria, different types of lavender (Lavandula spp.) belonging to the Labiatae (Lamiaceae) family have long been used in dried and natural forms for both therapeutic (antibacterial, antifungal, and antidepressant) and cosmetic purposes. It is not yet clear precisely how essential oils promote these results; however, efforts have been made toward characterizing their constituent

Copyright: Laghouati, et al. Open Access. This article is distributed under the terms of the Creative Commons Attribution 4.0 International License (http://creativecommons.org/licenses/ by/4.0/), which permits unrestricted use, distribution, and reproduction in any medium, provided you give appropriate credit to the original author(s) and the source, provide a link to the Creative Commons license, and indicate if changes were made. The Creative Commons Public Domain Dedication waiver (http:// creativecommons.org/publicdomain/zero/1.0/) applies to the data made available in this article, unless otherwise stated. phenolic compounds [9]. Bozkurt et al. [10] have suggested that the antioxidant and antimicrobial properties of the phenolic compounds found in Lavandula stoechas (lavender oil [LO]) have a direct effect on growth performance, carcass characteristics, and meat quality in studies focused on poultry farming. Schweitzer [11] have suggested that the breeding conditions and physiological behavior of the Japanese quail Coturnix japonica are similar to those of the more familiar Gallus spp. Some studies on quail farming have already been conducted at a national level $[12,13]$.

In line with these works, the aim of this study was to determine the physiologic effects of LO provided to quails as a dietary supplement.

\section{Materials and Methods}

\section{Ethical approval}

The present study was conducted after obtaining the approval $\mathrm{n}^{\circ} 05 / \mathrm{UG} / 18$ of the Institutional Animal Ethics Committee, Laboratory of Agriculture Department, University of Ghardaia, Algeria.

\section{Study period and study location}

Animals, diets, and experimental protocol

In total, 600 1-day-old quail chicks (C. japonica), with an average weight of $6.8 \pm 0.2 \mathrm{~g}$ and a $1: 1$ sex ratio, were randomly assigned to four groups 
(150 chicks/group): One control group and three distinct experimental groups (Table-1). Each group of 150 quails was divided into five subgroups of 30 quails. All were housed on a litter of sieved wood chips in a closed building with a static ventilation system in the municipality of Tébessa, Tébessa Province, Algeria. During the $1^{\text {st }}$ week of the experiment, the average temperature was maintained at $39^{\circ} \mathrm{C}$; the temperature was then reduced to $36^{\circ} \mathrm{C}$ during the growth phase and maintained at $24^{\circ} \mathrm{C}$ during the finishing stage. Lighting was provided $24 \mathrm{~h}$ /day during the first 2 weeks of the study and 12 hours for the rest of the experiment. The diets were formulated in accordance with the directives of the nutrient requirements of domestic chickens [14]. The ingredients and nutritional value of the two diets provided during each phase of breeding are indicated in Table- 2 . L. stoechas was harvested at the flowering stage from the municipality of Bougous, El Taref, Algeria. The essential oil was obtained by low-pressure steam distillation following decantation into a Florentine vase. The main constituents of the extract are included in Table-3. In the three experimental groups, LO was added to soya bean oil at a rate of $1 \mathrm{~g} / \mathrm{kg}$ of feed and distributed either sequentially or not, according to the protocol in Table-1. During every phase of breeding, water and feed were distributed ad libitum, and any feed not eaten was weighed on a daily basis. The 150 quails in the control group were vaccinated against Newcastle disease and infectious bronchitis when the chicks were 7 days old. The quails were weighed individually on the day they were received and at the end of each phase of the breeding process. Mortality rate, food consumption, daily weight gain (DWG), consumption index (CI), and average daily intake (ADI) were determined.

\section{Carcass characteristics and physicochemical analy- ses of the meat}

At the end of the finishing phase (day 43), the body weights of 50 of the quails in each of the four groups were measured. After slaughter, the warm carcasses, cold carcasses, viscera, edible offal (liver and gizzard), feet, heads, and feathers were all weighed. The meat removed from each quail was ground and homogenized. The moisture, ashes, protein content, and fat content were determined and calculated in accordance with AOAC [15]. The $\mathrm{pH}$ was measured as previously described by Korkeala et al. [16] in $2 \mathrm{~g}$ of muscle homogenate (Pectoralis superficialis) in $18 \mathrm{ml}$ of buffered iodoacetate. The $\mathrm{pH}$ was also measured at 1,24 , and $72 \mathrm{~h}$ postmortem by inserting the electrode of a pH meter directly into the pectoral muscle $(\sim 2 \mathrm{~cm}$ deep), as previously described by El Rammouz [17].

\section{Bacteriological analysis}

The droppings from each group were removed at the end of each breeding cycle. Microbiological analysis was conducted as per the guideline of AFNOR [18] to detect Salmonella. Furthermore, the
Table-1: Constitution of the different batches with and without LO.

\begin{tabular}{lll}
\hline Breeding phase & Start-growth & Finishing \\
\hline Control group & Without LO & Without LO \\
Experimental groups & & \\
$D_{\text {LO }}$ & With LO & Without LO \\
LO $_{\text {LO }}$ & Without LO & With LO \\
$D F_{\text {LO }}$ & With LO & With LO \\
\hline LO=Lavender oil & &
\end{tabular}

Table-2: Formulae $(\mathrm{kg} / 100 \mathrm{~kg}$ of feed) of feed distributed to the quail at start-growth (1-20 days) and during the finishing stage (21-42 days).

\begin{tabular}{lcc}
\hline Composition & Start-growth & Finishing \\
\hline Corn & 56 & 62 \\
Soya bean oil 44\% & 1.30 & 0.35 \\
Soya meal & 38.50 & 33.10 \\
Dicalcium phosphate & 3.30 & 3.60 \\
MVS flesh & 0.90 & 0.95 \\
Calculated nutritional values & & \\
Metabolisable energy (kcal/kg) & 2,840 & 2,920 \\
Fats (\%) & 4.50 & 3.70 \\
Raw proteins (\%) & 26 & 24.50 \\
Lysine (\%) & 1.7 & 1.36 \\
Methionine (\%) & 0.45 & 0.36 \\
Cysteine (\%) & 0.4 & 0.45 \\
\hline
\end{tabular}

CMV: Mineral and vitamin supplement composed of, calcium: $150,700 \mathrm{mg} / \mathrm{kg}$, sodium chloride: 332,000 $\mathrm{mg} / \mathrm{kg}$, Vitamin A: 800,000 UI, Vitamin D3: 150,000 UI, Vitamin E: $1500 \mathrm{mg} / \mathrm{kg}$, Vitamin K: $200 \mathrm{mg} / \mathrm{kg}$, Vitamin B1: $100 \mathrm{mg} / \mathrm{kg}$, Vitamin B2: $450 \mathrm{mg} / \mathrm{kg}$, Vitamin B3: $780 \mathrm{mg} / \mathrm{kg}$, Vitamin B6: $150 \mathrm{mg}$, Vitamin B12: $1 \mathrm{mg} / \mathrm{kg}$, PP: $1000 \mathrm{mg} / \mathrm{kg}$, folic acid: $50 \mathrm{mg} / \mathrm{kg}$, biotin: $1.5 \mathrm{mg} / \mathrm{kg}$, choline chloride: $35,000 \mathrm{mg} / \mathrm{kg}$, iron: $3600 \mathrm{mg} / \mathrm{kg}$, copper: $2250 \mathrm{mg} / \mathrm{kg}$, zinc: $7500 \mathrm{mg} / \mathrm{kg}$. The diets were formulated in accordance with the directives of the NRC (1994)

Table-3: Main components of $L$. stoechas essential oil.

\begin{tabular}{lc}
\hline Compounds & Proportion (\%) \\
\hline$\alpha$-pinène & 0.8 \\
Camphène & 1.5 \\
Delta-3-carène & 0.7 \\
1,8-cinéole & 19.3 \\
Fenchone & 30.2 \\
Camphre & 20.6 \\
Borneol & 0.4 \\
Acétate de Bornyl & 3.9
\end{tabular}

L. stoechas=Lavandula stoechas

antimicrobial activity of LO was evaluated by counting the colony-forming units, as previously described by Khaksar [19].

\section{Statistical analysis}

The different results were processed using the Microsoft Excel spreadsheet. The statistical analysis and comparison of averages between the different dietary schemes were conducted by means of the one-way analysis of variance (ANOVA) test using the Statistical Package for the Social Sciences software (SPSS Inc. version 25 Chicago, USA), then completed by means of the Student-Newman-Keuls and Duncan 
Table-4: Effect of introducing LO supplements on the weight growth and average DWG in quails.

\begin{tabular}{|c|c|c|c|c|c|c|}
\hline Groups & Control & $\mathbf{D}_{\text {LO }}$ & $\mathbf{F}_{\text {LO }}$ & $\mathbf{D F}_{\text {Lo }}$ & SEM & p-value \\
\hline \multicolumn{7}{|l|}{ Start-growth phase } \\
\hline Initial weight $(\mathrm{g})$ & 7 & 6.5 & 7 & 7 & 0.254 & 0.129 \\
\hline Body weight at 20 days & $111^{a}$ & $97^{b}$ & $106^{a b}$ & $113^{a}$ & 10.83 & 0.019 \\
\hline DWG $1-20$ days ( $\mathrm{g} / \mathrm{d} /$ subject) & $5.21^{\mathrm{b}}$ & $4.54^{d}$ & $4.95^{c}$ & $5.33^{a}$ & 0.951 & 0.006 \\
\hline \multicolumn{7}{|l|}{ Finishing phase } \\
\hline Body weight at 42 days & $205^{b}$ & $201^{\mathrm{c}}$ & $207^{a b}$ & $209^{a}$ & 15.15 & 0.002 \\
\hline DWG $21-42$ days $(\mathrm{g} / \mathrm{d} /$ subject $)$ & $4.48^{c}$ & $4.95^{a}$ & $4.81^{\mathrm{b}}$ & $4.57^{c}$ & 1.18 & 0.002 \\
\hline DWG $1-42$ days ( $\mathrm{g} / \mathrm{d} /$ subject) & $4.84^{b}$ & $4.74^{c}$ & $4.87^{b}$ & $4.93^{a}$ & 1.58 & 0.005 \\
\hline
\end{tabular}

$\mathrm{LO}=$ Lavender oil, DWG=Daily weight gain. In each line, the numbers followed by the same exponents do not differ significantly at $p<0.05$

Table-5: Effect of introducing LO supplements on the ADI and the CI in quails.

\begin{tabular}{|c|c|c|c|c|c|c|}
\hline Groups & Control & $\mathbf{D}_{\text {LO }}$ & $\mathbf{F}_{\text {LO }}$ & $\mathbf{D F}_{\text {LO }}$ & SEM & p-value \\
\hline \multicolumn{7}{|c|}{ ADI (kg/subject) } \\
\hline $1-20$ days & $0.40^{c}$ & $0.38^{c}$ & $0.52^{\mathrm{b}}$ & $0.57^{a}$ & 0.125 & 0.03 \\
\hline 21-42 days & $1.15^{\mathrm{a}}$ & $1.02^{\mathrm{b}}$ & $0.97^{c}$ & $1.02^{\mathrm{b}}$ & 0.95 & 0.02 \\
\hline 1-42 days & $1.55^{\mathrm{b}}$ & $1.0^{\mathrm{d}}$ & $1.49^{c}$ & $1.59^{a}$ & 0.23 & 0.001 \\
\hline \multicolumn{7}{|c|}{ Consumption index } \\
\hline $1-20$ days & $4.44^{c}$ & $4.49^{c}$ & $4.96^{b}$ & $5.05^{a}$ & 1.78 & 0.03 \\
\hline 21-42 days & $6.38^{a}$ & $4.93^{b}$ & $4.69^{c}$ & $4.89^{b}$ & 1.65 & 0.02 \\
\hline $1-42$ days & $5.74^{a}$ & $4.46^{d}$ & $4.78^{c}$ & $4.94^{b}$ & 1.08 & 0.001 \\
\hline
\end{tabular}

$\mathrm{LO}=$ Lavender oil, $\mathrm{ADI}=$ Average daily intake, In each line, the numbers followed by the same exponents do not differ significantly at $\mathrm{p}<0.05$

test if the ANOVA test displayed a significant difference from the error risk of $5 \%(p<0.05)$.

\section{Results}

\section{Zootechnical performance}

No mortality was reported among any of the groups during the entire 42-day breeding period. Introduction of the LO supplement led to a significant reduction in the final live weights and the DWG of the $\mathrm{D}_{\mathrm{LO}}$ group compared with that of the control group; by contrast, we observed significant increases in both final live weights and DWG of the $\mathrm{F}_{\mathrm{LO}}$ and $\mathrm{DF}_{\mathrm{LO}}$ groups compared with those of the controls $(\mathrm{p}<0.002$; Table-4). The DWG over days $1-42$ was relatively high in the $\mathrm{DF}_{\mathrm{LO}}$ group, intermediate in the $\mathrm{F}_{\mathrm{LO}}$ and control groups, and minimal in the $\mathrm{D}_{\mathrm{LO}}$ group $(\mathrm{p}<0.005)$. The control and $\mathrm{DF}_{\mathrm{LO}}$ groups had similar DWG over days 21-42, whereas these measurements in the $\mathrm{F}_{\mathrm{LO}}$ and $\mathrm{D}_{\mathrm{LO}}$ groups were significantly higher, particularly in the $\mathrm{D}_{\mathrm{LO}}$ group $(\mathrm{p}<0.002)$.

The ADI of the $\mathrm{DF}_{\mathrm{LO}}$ group was the highest among all the four groups at $0.57 \mathrm{~kg} /$ quail $(\mathrm{p}<0.03)$ during the initial growth phase; the ADI during the finishing phase $(1.02 \mathrm{~kg}$ /quail) was equivalent to that of the $\mathrm{D}_{\mathrm{LO}}$ group (Table-5). During the entire breeding phase, the ADI of the $\mathrm{DF}_{\mathrm{LO}}$ group was highest $(1.59 \mathrm{~kg} /$ quail; $\mathrm{p}<0.001)$; and the CI was highest for the control group (5.74) and lowest for the $\mathrm{D}_{\mathrm{LO}}$ group (4.46; $\mathrm{p}<0.01)$. The $\mathrm{F}_{\mathrm{LO}}$ and $\mathrm{DF}_{\mathrm{LO}}$ groups displayed intermediate consumption indices.

\section{Carcass characteristics and meat quality}

The carcass characteristics and physicochemical properties of the meat varied significantly in response to the addition of LO to the diet $(\mathrm{p}<0.05$;
Table-6). The weights of the gizzard, legs and head; $\mathrm{pH}$ measurements at $1 \mathrm{~h}$ postmortem; and protein levels were not affected by the introduction of LO. However, LO in the feed was associated with increases in both warm and cold carcass weights, carcass yield, and feather weights, as well as in the water content of the meat in the $\mathrm{DF}_{\mathrm{LO}}$ group $\left(\mathrm{DF}_{\mathrm{LO}}>\right.$ control; $\mathrm{p}<0.05)$. The weight of the livers, the $\mathrm{pH}$ at 24 and $72 \mathrm{~h}$ postmortem, and the ash content of the meat were also modified significantly in response to the addition of LO ( $<<0.05$ vs. control group). Furthermore, a considerable reduction in the weight of the viscera was observed among quails in the $\mathrm{F}_{\mathrm{LO}}$ group compared with those in the other groups. The fat content of the meat increased significantly with the addition of LO to the diet in all three experimental groups, although these results did not reach statistical significance.

\section{Antimicrobial activity of LO}

The evaluation of antimicrobial activity of LO revealed a significant difference among the groups during the breeding phases (Table-7). A significant reduction in Lactobacillus spp. was observed throughout; reductions in Staphylococcus aureus and Escherichia coli were observed in the $\mathrm{DF}_{\mathrm{LO}}$ group compared with the other experimental groups and the control group $(p<0.05)$. The sequential addition of LO provided no conclusive results with regard to the microbial load.

\section{Discussion}

The addition of LO to quail feed throughout the breeding period (days 1-42) and specifically during the finishing period (days 21-42) resulted in 
Table-6: Effect of introducing LO supplement on the carcass characteristics and physicochemical properties of meat in quails.

\begin{tabular}{|c|c|c|c|c|c|c|}
\hline Groups & Control & $\mathbf{D}_{\text {LO }}$ & $\mathbf{F}_{\mathrm{LO}}$ & $\mathbf{D F}_{\text {LO }}$ & SEM & p-value \\
\hline \multicolumn{7}{|l|}{ Carcass characteristic } \\
\hline Live weight $(\mathrm{g})$ & 207 & 205 & 207 & 208 & 1.24 & NS \\
\hline Warm carcass weight $(\mathrm{g})$ & $155^{\mathrm{b}}$ & $154^{b}$ & $154^{\mathrm{b}}$ & $159^{a}$ & 1.56 & 0.04 \\
\hline Warm carcass yield & $0.75^{b}$ & $0.75^{b}$ & $0.74^{b}$ & $0.76^{a}$ & 1.66 & 0.01 \\
\hline Cold carcass weight $(\mathrm{g})$ & $154^{\mathrm{b}}$ & $152^{\mathrm{b}}$ & $153^{\mathrm{b}}$ & $158^{\mathrm{a}}$ & 1.54 & 0.03 \\
\hline Cold carcass yield & $0.74^{b}$ & $0.74^{\mathrm{b}}$ & $0.74^{\mathrm{b}}$ & $0.76^{a}$ & 1.89 & 0.02 \\
\hline Weight of viscera $(\mathrm{g})$ & $30^{a}$ & $29^{a}$ & $27^{b}$ & $30^{\mathrm{a}}$ & 0.63 & 0.02 \\
\hline Viscera yield & $0.14^{a}$ & $0.14^{a}$ & $0.13^{\mathrm{b}}$ & $0.14^{\mathrm{a}}$ & 0.03 & 0.01 \\
\hline Weight liver (g) & $6.60^{\mathrm{a}}$ & $5.50^{\mathrm{b}}$ & $5.30^{\mathrm{b}}$ & $5.40^{\mathrm{b}}$ & 1.32 & 0.03 \\
\hline Liver yield & $0.032^{\mathrm{a}}$ & $0.027^{b}$ & $0.026^{b}$ & $0.026^{\mathrm{b}}$ & 0.003 & 0.01 \\
\hline Weight gizzard (g) & 5.20 & 5.16 & 5.18 & 5.15 & 0.21 & NS \\
\hline Gizzard yield & 0.025 & 0.025 & 0.025 & 0.025 & 0.002 & NS \\
\hline Weight of head $(\mathrm{g})$ & 12.60 & 12.40 & 12.50 & 12.30 & 1.02 & NS \\
\hline Head yield & 0.061 & 0.060 & 0.060 & 0.059 & 0.001 & NS \\
\hline Weight of feet $(\mathrm{g})$ & $4.2^{\mathrm{a}}$ & 4.00 & 4.00 & 4.10 & 1.25 & NS \\
\hline Feet yield & 0.020 & 0.019 & 0.019 & 0.020 & 0.02 & NS \\
\hline Weight of feathers $(\mathrm{g})$ & $14.40^{c}$ & $15.00^{b}$ & $15.10^{\mathrm{b}}$ & $15.40^{\mathrm{a}}$ & 2.01 & 0.02 \\
\hline Feathers yield & $0.070^{c}$ & $0.073^{b}$ & $0.073^{b}$ & $0.074^{a}$ & 0.05 & 0.02 \\
\hline \multicolumn{7}{|c|}{ Physical-chemical properties of the meat } \\
\hline $\mathrm{pH} 1 \mathrm{~h}$ postmortem & 6.41 & 6.44 & 6.42 & 6.40 & 1.23 & NS \\
\hline $\mathrm{pH} 24 \mathrm{~h}$ postmortem & $7.42^{\mathrm{a}}$ & $7.37^{\mathrm{b}}$ & $7.31^{\mathrm{b}}$ & $7.33^{\mathrm{b}}$ & 1.54 & 0.04 \\
\hline $\mathrm{pH} 72$ h postmortem & $8.20^{a}$ & $7.97^{b}$ & $7.96^{b}$ & $7.98^{\mathrm{b}}$ & 0.98 & 0.03 \\
\hline Water content ( $\%$ of DM) & $52.73^{b}$ & $46.85^{c}$ & $46.98^{c}$ & $55.90^{a}$ & 2.32 & 0.01 \\
\hline Ash (\% of DM) & $1.36^{\mathrm{a}}$ & $1.29^{\mathrm{b}}$ & $1.21^{\mathrm{b}}$ & $1.07^{c}$ & 0.25 & 0.02 \\
\hline Protein content ( $\%$ of DM) & 19.20 & 19.17 & 19.18 & 19.21 & 2.65 & NS \\
\hline Fat level (\% of DM) & $5.17^{b}$ & $5.34^{a}$ & $5.31^{\mathrm{a}}$ & $5.32^{\mathrm{a}}$ & 1.36 & 0.04 \\
\hline
\end{tabular}

$\mathrm{LO}=$ Lavender oil, In each line, the numbers followed by the same exponents do not differ significantly at $p<0.05$

Table-7: Effect of introducing LO supplement on the development of seeds in quail droppings. Figures presented in log $\mathrm{UFC} / \mathrm{g}$.

\begin{tabular}{lcccccc}
\hline Groups & Control & $\mathbf{D}_{\text {LO }}$ & $\mathbf{F}_{\text {LO }}$ & DF $_{\text {Lo }}$ & SEM & P-value \\
\hline Start of growth phase & & & & & & \\
$\quad$ E. coli & $9.50^{\mathrm{a}}$ & $9.35^{\mathrm{a}}$ & $9.51^{\mathrm{a}}$ & $8.34^{\mathrm{b}}$ & 0.254 & 0.012 \\
Lactobacilli & $7.10^{\mathrm{a}}$ & $7.10^{\mathrm{a}}$ & $7.13^{\mathrm{a}}$ & $6.11^{\mathrm{b}}$ & 1.83 & 0.019 \\
Salmonellae & Absence & Absence & Absence & Absence & $/$ & $/$ \\
S. aureus & $7.30^{\mathrm{a}}$ & $7.35^{\mathrm{a}}$ & $7.13^{\mathrm{b}}$ & $7.10^{\mathrm{b}}$ & 2.08 & 0.01 \\
Finishing phase & & & & & & \\
E. coli & $9.79^{\mathrm{a}}$ & $9.66^{\mathrm{a}}$ & $9.73^{\mathrm{a}}$ & $7.60^{\mathrm{b}}$ & 12.54 & 0.008 \\
Lactobacilli & $7.34^{\mathrm{a}}$ & $7.33^{\mathrm{a}}$ & $7.11^{\mathrm{b}}$ & $7.12^{\mathrm{b}}$ & 1.18 & 0.002 \\
Salmonellae & Absence & Absence & Absence & Absence & $/$ & $/$ \\
S. aureus & $7.35^{\mathrm{a}}$ & $7.30^{\mathrm{a}}$ & $7.10^{\mathrm{b}}$ & $7.09^{\mathrm{b}}$ & 1.98 & 0.01 \\
\hline
\end{tabular}

E. coli=Escherichia coli, S. aureus=Staphylococcus aureus, LO=Lavender oil, In each line, the numbers followed by the same exponents do not differ significantly at $p<0.05$

improvements in both final live weight and DWG. This trend is similar to that reported by NasiriMoghaddam et al. [20], who reported that the addition of $350 \mathrm{ppm}$ of essential oil of lavender (Lavandula angustifolia) to the diet of broiler chickens resulted in increased live weights during the 22-42 day interval. By contrast, Küçükyilmaz et al. [9] reported that diets supplemented with 24 or $48 \mathrm{mg}$ of EOLS per $\mathrm{kg}$ feed had no effect on the final body weight of 39-day-old broiler chickens. In accordance with these findings, the study conducted by Salajegheh et al. [21] demonstrated that adding $1 \%$ herbal powder of $L$. angustifolia to broiler feed resulted in significant increases in weight gain during all breeding phases (growth and finishing). In their recent study, AdaszyńskaSkwirzyńska and Szczerbińska [22] also showed that addition of essential oil of lavender (L. angustifolia) to the drinking water of broiler chickens had a positive effect on final live weight and DWG during the entire breeding period (days 1-42), most notably on days 22 and 24.

The addition of LO during the entire 42-day breeding period resulted in a reduction in both the amount eaten and the CI. Interestingly, Mokhtari et al. [23] and Küçükyilmaz et al. [9] found that addition of LO had no effect on either of these two parameters, although Bozkurt et al. [10] found that addition of essential oil derived from plants of the family Labiatae stimulated the growth in broiler chickens. Furthermore, the quantity of LO distributed $(1 \mathrm{~g} / \mathrm{kg}$ feed) may have an effect on these results [24]. Kanyinji and Moonga [25] reported that high consumption 
indices could be linked to wasteful behaviors. Finally, while there are only a few studies that address this point, the addition of LO to quail feed generates contradictory results with regard to other essential oils $[19,26,27]$.

We also found that the addition of LO during all breeding phases resulted in significant differences in the characteristics of the carcass and the physicpchemical properties of the meat. These findings included a significant increase in both warm and cold carcass weights, carcass yield, and feather weights; interestingly, we observed no effect on live weight or the weights of the feet, head and gizzards, similar to results reported previously [9]. The effect of LO on the weight and development of the gizzard may be neutral due to the nature of its physiological function $[27,28]$, although several groups have noted that administration of LO resulted in smaller livers. It is important to recognize that these findings are not specific to LO [29], although Biricik et al. [26] reported that administration of essential oil of myrtle (EOM) had no significant effect on liver weight.

Adding LO to the quails' diet had no effect on meat $\mathrm{pH}$ determined at $1 \mathrm{~h}$, but resulted in a significant reduction in $\mathrm{pH}$ at both 24 and $72 \mathrm{~h}$ postmortem. These results stand in contrast to those of Biricik et al. [26] who reported that addition of EOM had no significant effect on the $\mathrm{pH}$ of quail meat. By contrast, Aksu et al. [30] observed a significant increase in the $\mathrm{pH}$ of breast filets in response to EOM and concluded that the final $\mathrm{pH}$ was affected by numerous factors including age, sex, breeding methods, feed additives, stress before slaughter, hormonal status, muscle morphology, and glycogen content.

We also found that administration of LO throughout the breeding process resulted in an increase in fat content and water content accompanied by a decrease in ash content of the quail meat; interestingly, we observed no effect on protein content. This result was similar to that reported by Bolukbasi et al. [31] but was contradictory to that of Fotea et al. [32] who reported that this intervention resulted in no changes whatsoever in the chemical composition of broiler chicken meat. Alleman et al. [33] also noted several varied effects of essential oils on the physicochemical properties of meat.

Finally, we examined the effect of LO on gut bacterial content. We noted the complete absence of contaminating Salmonella spp.; bacteria of the genera Lactobacillus are components of the endogenous bacterial microbiome. Ramdane and Guitarni [34] reported that the quail's digestive tract is sterile before birth and that the appearance of intestinal flora depends on the nature of the immediate environment of the egg at the time of hatching. This trend has also been observed by Fuller [35], who detected lactobacilli in the digestive tract of chicks beginning on day 3 after hatching. Furthermore, the number of colony-forming units of $E$. coli and $S$. aureus was diminished in the experimental groups. These findings are consistent with those of Boughendjioua [36], who observed that E. coli are sensitive to LO. Several other studies, notably those of Derwich et al. [37] and Bari et al. [38], reported a high level of resistance to LO among Gram-negative bacteria as opposed to Grampositive bacteria. These results might be explained by the relative volatility of essential oils and likewise, due to the lipopolysaccharide content at the Gramnegative bacterial surface that might serve as an effective barrier to incoming biomolecules [35]. This trend was reported by Dorman and Deans [39], who noted that the different components of essential oils demonstrate varying degrees of activity against Gramnegative versus Gram-positive bacteria; the chemical composition of essential oils may vary according to both intrinsic and extrinsic factors [40]. According to Botsoglou et al. [41], healthy, well-fed chicks do not typically respond to supplements that promote growth when they are housed with only basic hygienic management.

\section{Conclusion}

Supplementation of quail feed with LO facilitated specific improvements in zootechnical performance, carcass weight, and carcass yield, as well as the physicochemical properties of the quail meat. Microbial loads were reduced and the health status of the quails was improved.

\section{Authors' Contributions}

OL prepared the ground conditions and collected the data. YA performed the analysis of the data. FA designed the study and drafted the manuscript. All authors have read and approved the final manuscript.

\section{Acknowledgments}

We would like to thank our respective university, University of Chadli bendjedid, El Tarf, University of Ghardaia, Algeria and University of Sétif 1, Algeria, for their help. The authors declare that they did not have any funding source or grant to support this research work.

\section{Competing Interests}

The authors declare that they have no competing interests.

\section{Publisher's Note}

Veterinary World remains neutral with regard to jurisdictional claims in published institutional affiliation.

\section{References}

1. Popović, S., Puvača, N., Kostadinović, L., Džinić, N., Bošnjak, J., Vasiljević, M. and Djuragic, O. (2016) Effects of dietary essential oils on productive performance, blood lipid profile, enzyme activity and immunological response of broiler chickens. Eur. Poult. Sci., 80: 1-12.

2. Kirimer, N., Mokhtarzadeh, S., Demirci, B., Goger, F., Khawar, K.M. and Demirci, F. (2017) Phytochemical 
profiling of volatile components of Lavandula angustifolia Miller propagated under in vitro conditions. Ind. Crops Prod., 96: 120-125.

3. Carrasco, A., Martinez-Gutierrez, R., Tomas, V. and Tudela, J. (2016) Lavandula angustifolia and Lavandula latifolia essential oils from Spain: Aromatic profile and bioactivities. Planta Med., 82(1-2): 163-170.

4. Giovannini, D., Gismodni, A., Basso, A., Canuti, L., Braglia, R., Canini, A., Mariani, F. and Cappelli, G. (2016) Lavandula angustifolia Mill. Essential oil exerts antibacterial and anti-inflammatory effect in macrophage mediated immune response to Staphylococcus aureus. Immunol. Invest., 45(1): 11-28.

5. Saleh, A.A. (2014) Nigella seed oil as alternative to avilamycin antibiotic in broiler chicken diets. S. Afr. J. Anim. Sci., 44(3): 254-261.

6. Saleh, A.A., Ijiri, D. and Ohtsuka, A. (2014) Effects of summer shield supplementation on the growth performance, nutrient utilization, and plasma lipid profiles in broiler chickens. J. Vet. Med., 59(11): 536-542.

7. Saleh, A.A., Ebeid, T.A. and Abudabos, A.M. (2018) Effect of dietary phytogenics (herbal mixture) supplementation on growth performance, nutrient utilization, antioxidative properties and immune response in broilers. Environ. Sci. Pollut. Res., 25(15): 14606-14613.

8. Saleh, A.A., Ahmed, E.A. and Ebeid, T.A. (2019) The impact of phytoestrogen source supplementation on reproductive performance, plasma profile, yolk fatty acids and antioxidative status in aged laying hens. Reprod. Domest. Anim., 54(6): 846-854.

9. Küçükyilmaz, K., Kiyma, Z., Akdağ, A., Çetinkaya, M., Atalay, H., Ateş, A., Gürsel, F.E. and Bozkurt, M. (2017) Effect of lavender (Lavandula stoechas) essential oil on growth performance, carcass characteristics, meat quality and antioxidant status of broilers. S. Afr. J. Anim. Sci., 47(2): 178-186.

10. Bozkurt, M., Küçükyılmaz, K., Çatlı, A.U., Özyıldız, Z., Çınar, M., Çabuk, M. and Çöven, F. (2012) Influences of an essential oil mixture supplementation to corn versus wheatbased practical diets on growth, organ size, intestinal morphology and immune response of male and female broilers. Ital. J. Anim. Sci., 11(3): 290-297.

11. Schweitzer, C. (2009) Characterization of Social Links In Japanese Quail (Coturnix japonica): Social Motivation and Relationship Between Familiars. Doctoral thesis François University, France.

12. Moula, N., Philippe, F.X., Kaki, A.A., Touazi, L., AntoineMoussiaux, N. and Leroy, P. (2014) Laying and eggs quality of quails in semi-intensive conditions in Eastern Algeria Arch. Zootec., 63(244): 693-696.

13. Ferrouk, M., Boukenaoui, N., Smaili, I., Samad, I.A. and Exbrayat, J.M. (2015) Morphometric and histological study of the testicle of the Japanese quail (Coturnix japonica) during postnatal growth.. Bull. Soc. Zool. Fr., 140(1): 45-60.

14. NRC (1994) National Research Council. Nutrients Requirements of quails. National academy Press Washington, DC, USA.

15. AOAC, (1990) Official Method of Analysis, 15th edition. Association of Analytical Chemists, Inc. Arlington, Virginia, USA

16. Korkeala, H., Mäki-Petais, O., Alanko, T. and Sorvettula, O. (1984) Determination of $\mathrm{pH}$ in meat. Meat Sci., 18: 121-125.

17. El Rammouz, R. (2005) Study of Post Mortem Biochemical Changes in the Muscle of Poultry - Contribution to the Determinism of the Amplitude of the Decrease in ph. Doctoral thesis, Institut National Polytechnique de Toulouse, France.

18. AFNOR (2005) Association French Normalization Organization Regulation method (NF U 47- 100 2005) France.
19. Khaksar, V., Krimpen, M., Hashemipour, H. and Pilevar, M. (2012) Effects of thyme essential oil on performance, some blood parameters and ileal microflora of Japanese Quail. J. Poult. Sci., 49(2): 106-110.

20. Nasiri-Moghaddam, H., Hassanabadi, A. and Bidar, N. (2012) Effects of increasing levels of lavender essential oil (Lavandula angustifolia) on performance and hematological traits of broilers. Iran. J. Anim. Sci. Res., 4: 115-121.

21. Salajegheh, A., Salarmoini, M., Afsharmanesh, M. and Salajegheh, M.H. (2018) Growth performance, intestinal microflora, and meat quality of broiler chickens fed lavender (Lavandula angustifolia) powder. J. Livest. Sci. Technol., 6(1): 31-38.

22. Adaszyńska-skwirzyńska, M. and Szczerbińska, D. (2019) The effect of lavender (Lavandula angustifolia) essential oil as a drinking water supplement on the production performance, blood biochemical parameters, and ileal microflora in broiler chickens. Poult. Sci., 98(1): 358-365.

23. Mokhtari, S., Rahati, M., Seidavi, A., Haq, Q.M.I., Kadim, I., Laudadio, V. and Tufarelli, V. (2018) Effects of feed supplementation with lavender (Lavandula angustifolia) essence on growth performance, carcass traits, blood constituents and caecal microbiota of broiler chickens. Eur. Poult. Sci., 82: 1-11.

24. Alkan, S., Karabag, K., Galic, A., Karsli, T. and Balcioglu, M.S. (2010) Determination of body weight and some carcass traits in japanese quails (Coturnix coturnix Japonica) of different lines. Kafkas Univ. Vet. Fak. Derg., 16(2): 277-280.

25. Kanyinji, F. and Moonga, M. (2014) Effects of replacing maize meal with rumen filtrate-fermented cassava meal on growth and egg production performance in Japanese quails (Coturnix japonica). J. Adv. Vet. Anim. Res., 1(3): 100-106.

26. Biricik, H., Yesilbag, D., Gezen, S.S. and Bulbul, T. (2012) Effects of dietary myrtle oil (Myrtus communis L.) supplementation on growth performance, meat oxidative stability, meat quality and erythrocyte parameters in quails. Rev. Med. Vet., 163(3): 131-138.

27. Gumus, R., Ercan, N. and Imik, H. (2017) The effect of thyme essential oil (Thymus vulgaris) added to quail diets on performance, some blood parameters, and the antioxidative metabolism of the serum and liver tissues. Rev. Bras. Cienc. Avic., 19(2): 297-304.

28. Omonona, A.O., Olukole, S.G. and Fayemi, O.O. (2014) Assessment of the developmental anatomy of the Japanese quail (Coturnix japonica) using the gizzard as a growth indicator. Polym. Adv. Technol., 10(2): 12-21.

29. Mansoub, N.H. (2011) The evaluation of different levels of Mentha pulegium on performance, and blood parameters of broilers. J. Am. Sci., 7: 338-341.

30. Aksu, T., Aksu, M.İ., Önel, S.E., Yakan, A., Kaya, D.A. and Baylan, M. (2013) Effect of thyme oil (Thymbra spicata L. Var. Spicata) on meat quality in Japanese quails. Eur. Poult. Sci., 78(1): 1-11.

31. Bolukbasi, S.C., Erhan, M.K. and Ozkan, A. (2006) Effect of dietary thyme oil and Vitamin $\mathrm{E}$ on growth, lipid oxidation, meat fatty acid composition and serum lipoproteins of broilers. S. Afr. J. Anim. Sci., 36(3): 189-196.

32. Fotea, L., Costachescu, E. and Hoha, G. (2009) The effect of essential oil of rosemary (Rosmarinus officinalis) on the broilers growing performances Lucrari StiintificeUniversitatea de Stiinte Agricole si Medicina Veterinara. Ser. Zooteh., 52: 111-113.

33. Alleman F, Gabriel I., Dufourcq V, Perrin F, Gabarrou J.-F. (2013) Use of essential oils in poultry feed. 1. Growth performance and regulations. INRA Prod. Anim., 26(1): 3-12. .

34. Ramdane, M.S. and Guitarni, D. (2008) Effects of probiotics on 3 germs of the intestinal flora of broilers. Horticulture, 65(2): 614-620.

35. Fuller, R. (1989) Probiotic in man and animals. J. Appl. Bacteriol., 66(5): 365-378.

36. Boughendjioua, H. (2017) Chemical composition and 
antibacterial activity of essential oil of Lavandula officinalis grown in the region of Skikda-Algeria Bull. Soc. R. Sci. Liège, 86: 88-95.

37. Derwich, E., Benziane, Z. and Boukir, A. (2010) GC/MS: Analysis and antibacterial activity of the essential oil of Mentha pulegium grown in Morocco. J. Agric. Biol. Sci., 6(3): 191-198

38. Bari, M.A., Islam, W., Khan, A.R. and Mandal, A. (2010) Antibacterial and antifungal activity of Solanum torvum (Solanaceae). Int. J. Agric. Biol., 12(3): 386-390.
39. Dorman, H.J.D., and Deans, S.G. (2000) Antimicrobial agents from plants: Antibacterial activity of plant volatile oils. J. Appl. Microbiol., 88(2): 308-316.

40. Lahlou, M. (2004) Methods to study phytochemistry and bioactivity of essential oils. Phytother. Res., 18(6): 435-448.

41. Botsoglou, N.A., Christaki, E., Florou-Paneri, P., Giannenas, I., Papageorgiou, G. amd Spais, A.B. (2004) Effect of a mixture of herbal essential oils or $\alpha$-tocopheryl acetate on performance parameters and oxidation of body lipid in broilers. S. Afr. J. Anim. Sci., 34(1): 52-61.

\section{$* * * * * * * *$}

